\title{
THE ROLE OF BUSINESS IN BUILDING A SUSTAINABLE ECONOMY Current status and future directions
}

\author{
Rade Glomazic ${ }^{1}$ \\ Susannah Goh ${ }^{2}$ \\ Aoife O' Brien ${ }^{3}$ \\ Deb Conner ${ }^{4}$ \\ Julio Bin 5
}

\begin{abstract}
There is a rapidly expanding body of work that describes what needs to be done by business to belp build a sustainable economy. A review of the literature from academia, the public sector and business itself provides key principles of "sustainable businesses". Yet, movement toward a sustainable economy is currently fragmented and with limited large-scale direction. Thispaper aims to explore the relationship between business and a sustainable economy, and what it takes to connect the two. Initially a survey of literary consensus that evidences an unsustainable current economic model is presented in the paper. Then a review of the current understanding of the role of business in making the transition to a sustainable economy is offered. Followed by an analysis of primary and secondary research exploring the perception of leading enterprises of their own role, and compare this with evidence-based reality. As a research will show the companies surveyed consider sustainability as crucial to their
\end{abstract}

${ }^{1}$ Mr. Rade Glomazic, MBA, MSc, Doctoral Candidate, European Center for Peace and Development of the University for Peace established by the UN, Belgrade, Serbia. email: glomazic@post.harvard.edu

2 Ms. Susannah Goh, BA (Hons), PCSB. Birmingham Science City- Aston University, Birmingham, UK. email: s.goh@aston.ac.uk

3 Ms. Aoife O' Brien, BA, Grad Dip in IT, Post Grad in Sustainable Business, Cambridge Sustainability Network, UK. email: aoifec.obrien@gmail.com

${ }^{4}$ Deb Conner, BA, Post Grad in Sustainable Business, Cambridge Sustainability Network, UK. email: debconner@googlemail.com

5 Mr. Julio Bin, BBA, PG Dip in Marketing, Post Grad in Sustainable Business, Cambridge Sustainability Network, UK. email: juliobin@gecko.com.br 
future business success (93\%) and governments as their most important influence in supporting sustainability decisions (80\%). Also research shows that $75 \%$ of companies recognize that it is important to merge sustainability and financial metrics in reporting. Finally, recommendations to support realistic models and pathways for change to a 'good economy'-an effective one which cares for human and other natural resources (CPSL. 2007) are provided. To ensure that 'leading' companies are leading others, actionable key points for companies that are not yet leaders of the future, but may become so, are identified.

Key words: Sustainable development / corporate governance / green economy / social responsibility

\section{INTRODUCTION}

If businesses do not have complete control of markets, products and consumers, in preserving or destroying today and tomorrow's human and natural resources, then they do have a great influence on them. Business therefore has a burgeoning role in creating a sustainable economy. A common definition of 'the economy' is, seemingly, straightforward: 'a system of production, distribution and consumption' (Wordnet, 2010) yet business' impacts on and the motivations within it are most certainly not.

The concept of 'sustainability' is enjoying a prominent position within the gameplans of an increasing number of business leaders, as was illustrated in this year's United Nations Global Compact survey (UNGC, 2010). Sustainability has come a fair distance from the seminal call by E.F. Schumacher to 'temper the economy as the helpmeet of humankind and nature, not vice-versa' (Schumacher, 1993). Currently, sustainability pioneers such as the UNGC respondents believe that the issues inherent in this concept are absolutely critical, not only to our planet, but to the current and future success of their businesses. Yet in practice this journey is not plain sailing. Implementing a truly effective and lasting sustainability strategy and delivery plan across all business functions is a highly complex task. We ask how today's pro-sustainability business leaders see their task and act on it, and how this matches up to what is really needed.

A great transition is required from 'business as usual' complacency to creating a world economy that works towards rather than against a long-term sustainable future. It requires radical mindset developments and practical changes within a business. For this reason, this paper homes in on the following: 
- What a sustainable economy should look like;

- What the current economic model promotes and how this compares to this sustainable economy ideal;

- The gaps between the ideal and the reality.

In exploring these leads, we will focus particularly on answering the following questions:

- What is the perceived role of business in creating a sustainable economy from the point of view of current sustainability leaders in business?

- How, in practice, do they measure up to their own ideals and objectives?

- How does this compare to what is needed to create a sustainable economy in practice?

In rising to the challenges that are presented, we aim to review the achievements and the shortfalls of those at the forefront of pro-sustainability business thinking. Our goal is to steer their course a little nearer towards a sustainable economy in the present, for the future and in the future.

\section{METHODOLOGY}

This section outlines how we have approached the research required to answer the question posed in this paper. An initial review of literature, including business reporting and academic and practitioner research, was carried out to provide the hermeneutical frameworks to support our research and its subsequent analysis. In particular, this review helped us to envision a sustainable economy and so judge the distance between it and the prevalent global economic model of today.

The 'sustainability economy' is a hot topic. Material published that specifically addresses the role of business in a sustainable future is growing rapidly. If we had been undertaking this research last year at least three of the central documents which have helped to shed light on the topic would not have been available.

From the springboard of much recent research by other authors, our research has been designed on a 'mixed method' basis, using quantitative methods to give precise and testable expressions to qualitative ideas. In order to gather the sample set for primary research about businesses' understanding of their role in building a 
sustainable economy, our research group compiled a list of 31 companies identified as leaders in sustainable practice. hree approaches were employed to do this:

First, the initial selection of leading businesses took place. A survey was sent out to 312 alumni of the Cambridge Postgraduate Certificate in Sustainable Business, wherein they were asked to identify companies they perceived to be leaders in sustainable business practice. Questions were posed using the CPSL (CPSL, 2007) 'sustainable economy' definition, to which representatives from 14 businesses responded recommending 71 companies as leaders in this field. To ensure an adequate sample to provide the depth of findings needed, further supplementation was made from the literature and from suggestions taken from the group members' own experience. This provided a further source of leading companies.

Second, company specific research was undertaken. In total, thirty-one leading companies were identified and approached (Fig 1). Before approaching them directly to gain primary information, secondary research was undertaken to identify companies' stance on values, business priorities, strategies and stakeholder relationships. This was done through desktop research via the internet and access to public domain company reports. Primary research followed in the form of interviews, which were conducted with 22 of these companies ( $77 \%$ of those approached).

\begin{tabular}{|l|l|}
\hline & Companies Researched and Interviewed: \\
\cline { 2 - 2 } & 16. Starbucks \\
1. Banco Real / Santander & 18. Vale \\
2. BASF & 19. Vodafone \\
3. Ben \& Jerry's & 20. Wal-Mart \\
4. Co-operative Group & 21. Westpac \\
5. EDF & 22. Pret \\
6. GE & 23. People Tree \\
7. Google & 24. Timberland \\
8. Interface & 25. Body Shop \\
9. John Lewis Partnership & 26. Royal Mail \\
11. Microsoft & 27. BT \\
12. Natura & 2B. Cisco \\
13. Novo Nordisk & 29. Arup \\
14. Otto Group & 30. Diageo \\
15. Patagonia & 31. Boots \\
\hline
\end{tabular}

Figure 1: Companies Researched and Interviewed. 
During these interviews further information was gathered specifically about the companies' visions, strategies and actions to promote and embed sustainability for the present and the future. Both primary and secondary investigations were designed using, primarily, the following sources: the 2010 UN Global Compact Survey by Accenture (UNGC. 2010), the Prince of Wales's Business and Environment Programme study (CPSL, 2006), and surveys by The Economist (Economist Intelligence Unit. 2007), Mc Kinsey and Company (Oppenheim et al. 2007) and - for qualitative data - CPSL's Sustainable Economy Dialogue (CPSL, 2007) and CPSL Next Economy Initiative (unpublished). These were selected as they provided the breadth of material to cover economic, social and environmental sustainability, whilst providing a depth of insight into business strategy and operations. From these we were able to take our cue and mine down further into our chosen topic.

Third, triangulation took place to validate our findings. We recognised that our research gives a depth of information. Yet, because of the small number of companies researched, we lacked initially the numerical validity to determine business trends amongst our leaders. Our findings were therefore triangulated against other research, predominantly the studies noted in the previous paragraph.

From the primary and secondary data gathered, descriptive statistics were analysed to form a picture of the value-based, strategic and operational priorities for sustainability leaders in business. And upon this picture the yardstick between their work and objective requirements for a sustainable economy was applied. The results of this 'measuring-up' form for the final conclusions of our paper.

\section{IS THE CURRENT ECONOMIC MODEL SUSTAINABLE?}

Today's predominant economic model is still heavily focussed on gross domestic product. Within this paradigm, 'success' and 'prosperity' are all about profit and growth, achieved by using human and natural resources. Little regard is given to their sustainability. Looking to the future, if global financial prosperity is to grow exponentially between 2014 and 2050, we would require an economy 15 times the size of our current economy. This is a demand that goes well beyond the constraints of nature. Humankind is running out of resources on which to live. As Jackson observes (Jackson, 2009), we need somehow to "decouple" notions of success and prosperity from escalating growth and greed. 
There is a distance between a sustainable economy and where the market sits currently. How do we bridge the gap? Governments have influence, but this is largely limited to their own nation states. If society wishes to make changes for the better it can lobby, opt out and so on. Yet mobilisations are heavily dependent on cultural and economic mores of any one generation and may not carry forward in the long term. Scale-wise, only businesses have global power through their buying and selling muscle. Time-wise, the market will exist longer than any single generation - money, for the foreseeable future, will remain humankind's currency. In addition, the business animal can mobilise, innovate and provide goods and services quicker and more efficiently than any state or individual. Leadership must be the obligation of businesses for these reasons.

\section{What is the role of business in developing a sustainable economy?}

Through our literature - based research it has become clear that there should be nuanced practical definitions of sustainability for business to follow. Helpfully, the table below indicates themes (and corresponding actions) suggested in the Sustainable Economy Dialogue research (CPSL, 2007):

\begin{tabular}{|c|c|}
\hline Thene & Action \\
\hline 1. Education & $\begin{array}{l}\text { Promote sustainability literaxy and awareness } \\
\text { among company's stakeholders }\end{array}$ \\
\hline 2. Gowemance & $\begin{array}{l}\text { Hold govemments to account on sustainability } \\
\text { through lobbying and partnerships }\end{array}$ \\
\hline 3. Long Termism & $\begin{array}{l}\text { Educate politicians and financiers on the long- } \\
\text { term nature of sustainability risks and returns }\end{array}$ \\
\hline 4. Equity & $\begin{array}{l}\text { Promote diversity and equity at the corporate, } \\
\text { community, national and international levels }\end{array}$ \\
\hline 5. Responsibility & $\begin{array}{l}\text { Commit to an agenda of accountability, transparency } \\
\text { and social and emironmental responsibility }\end{array}$ \\
\hline 6. Incentives & $\begin{array}{l}\text { Pressure govemments to create a level playing } \\
\text { field for fair and sustainable international trade }\end{array}$ \\
\hline 7. Extemalities & $\begin{array}{l}\text { Incomporate full cost accounting into long-term } \\
\text { investment decidions and begin to report on externslities }\end{array}$ \\
\hline 8. Purpose & $\begin{array}{l}\text { Engage in dialogue and partnership processes } \\
\text { to create a shared vision for a sustainable econony }\end{array}$ \\
\hline 9. Values & $\begin{array}{l}\text { Enbed values consistent with a sustainablity } \\
\text { approach into the company's culture and operations }\end{array}$ \\
\hline 10. Measures & $\begin{array}{l}\text { Measure and report on the indicatcos of governance, } \\
\text { social, ethical and environmental performance }\end{array}$ \\
\hline
\end{tabular}

Figure 2: Source: CPSL (2007).

The views of the authors we examined matched CPSL (2007) on most points. However, we discovered a small number of differences and additions. These can be summarised as follows: 
In our research businesses have been viewed predominantly as bodies to be lobbied and held to account, rather than as a lobby group for government (e.g. Jackson (2009) and Porritt, (2009)). On 'responsibility', our literature emphasised that the criteria had to be negotiated with external stakeholders in particular, so as to make accountability meaningful (e.g. Hart et al (2009) and UNGC (2010)).

Lastly, although sustainability measures were discussed widely, there was a noticeable lack of explicit suggestions for how social sustainability - as distinct from economic and environmental sustainability - could be included in proposed accounting methodologies and valuation systems (only Pearce et al (1989) and Stiglitz et al, (2009) mention this).

Our literature review reveals that pro-sustainability businesses sign up to the changes required socially, financially, politically and culturally. Their language is enthusiastic and heavily pro-active. However, to quote Jeffrey Sachs, a Millennium Development Goals adviser to the UN, this is sometimes the case: 'One could say there was a certain lack of seriousness in this process from the start' (Sachs. 2010). The perception of the role of business is embodied in their CSR reports, Codes of Conduct and willingness to participate in studies such as this. Yet most of businesses' innovation remains grounded primarily in government rules. The majority of pro-sustainability businesses do not challenge them, explore issues differently or move the debate forward. They are reactive rather than proactive. We have therefore asked our selected companies how they would go one or more steps further in challenging, exploring and progressing the current approaches, and thus be not just sustainability supporters, but sustainability leaders.

We may summarise the urgent issues as:

- Long-termism - Businesses cannot just rely on pressure from governments and society, because neither have the power nor longevity to make long-term changes to the economy.

- Combining and integrating capital values - From the Triple Bottom Line and the Five Capitals we learn that financial capital should be linked to at least one other capital, otherwise we do not pursue truly sustainable goals. The present economic situation is a painful reminder of what can go wrong if this is not heeded. 
- Decoupling - Definitions of success and prosperity must be decoupled from growth and consumption. We live with finite resources that may not be available to future generations.

\section{RESEARCH}

Having defined the essential objectives of a sustainable economy for the future and identified the current economy gaps in arriving there, we assessed the fundamental actions that could contribute to a good economy. In our research we concentrated on benchmarking selected companies' current activities with key actions suggested in the Sustainable Economy Dialogue research (CPSL, 2010). All data presented has been triangulated with other researches ${ }^{6}$ to support findings and to augment the confidence level of data that our research produced. Details of our primary research data findings and selection of key results from our company interviews will be articulated throughout the section.

2010 UN Global Compact Survey by Accenture (UNGC. 2010), the Prince of Wales's Business and Environment Programme study (CPSL, 2006), and surveys by The Economist (Economist Intelligence Unit. 2007), Mc Kinsey and Company (Oppenheim et al. 2007) and - for qualitative data - CPSL's Sustainable Economy Dialogue (CPSL, 2007) and CPSL Next Economy Initiative (unpublished) 


\section{1) Education}

Promote sustainability literacy and awareness among companies'stakeholders.

What is needed?

The Sustainable Economy Dialogue research shows that there is a lack of education and awareness around the links between the economy and sustainability. The UNGC survey found that $72 \%$ of CEOs see education as the global development issue that must be addressed urgently to ensure a sustainable future (UNGC, 2010).

What is actually being done?

\section{Table 1:}

\begin{tabular}{|l|c|}
\hline $\begin{array}{c}\text { Which of the following sustainable development issues are the most } \\
\text { critical to address for the future success of your business? }\end{array}$ \\
\hline Education & $21 \%$ \\
\hline Climate change & $31 \%$ \\
\hline Poverty & $10 \%$ \\
\hline Diversity and gender equity & $10 \%$ \\
\hline Health & $14 \%$ \\
\hline Social cohesion & $14 \%$ \\
\hline Other & $0 \%$ \\
\hline
\end{tabular}

Source: Questionnaire

Our research shows that concerns over education are, after climate change, the biggest single sustainability issue of our age. All interviewed companies believe that education should change in order to create sustainability leaders. Companies that we researched are taking positive steps to educate their staff and they also encourage customers to buy less and only buy what is needed. Businesses should take a cue from these corporations in designing specific educational initiatives rather than simply articulating the need for education.

\section{CONCLUSIONS:}

Education is a global issue perceived as a key element for the development of a sustainable economy. Companies may recognise the importance of the theme, but often invest their resources in educational or training programmes to enhance 
internal professional capabilities only. They all agree about the need for better sustainability literacy among stakeholders, but they still need more prominent and consistent initiatives within society in order to create awareness.

\section{2) Governance}

Hold government to account on sustainability through lobbying and partnership.

What is needed?

CPSL's Sustainable Economy Dialogue research shows that governments and related public institutions are ineffective in providing good governance and policies to embed sustainability. The UNGC survey of CEOs found that for $39 \%$ of companies, government is one of the main stakeholders influencing society expectations of business being sustainable. $24 \%$ of companies consider government regulations as a main motivational factor towards sustainability (UNGC).

What is actually being done?

Table 2:

\begin{tabular}{|c|c|c|c|c|}
\hline \multicolumn{5}{|c|}{$\begin{array}{l}\text { To what extent do you agree or disagree with each of the following statements } \\
\text { about the role of government and civil society over then next five years? }\end{array}$} \\
\hline & Strongly & Disagree & Agree & $\begin{array}{c}\text { Strongly } \\
+\end{array}$ \\
\hline $\begin{array}{l}\text { Governments and policy makers will increase } \\
\text { their interventions in driving sustainability }\end{array}$ & \multicolumn{2}{|c|}{$5 \%$} & \multicolumn{2}{|c|}{$95 \%$} \\
\hline $\begin{array}{l}\text { My company would welcome increased } \\
\text { government support to drive sustainability }\end{array}$ & \multicolumn{2}{|c|}{$15 \%$} & \multicolumn{2}{|c|}{$85 \%$} \\
\hline $\begin{array}{l}\text { My company will influence government } \\
\text { to promote a sustainable future }\end{array}$ & \multicolumn{2}{|c|}{$20 \%$} & \multicolumn{2}{|c|}{$80 \%$} \\
\hline $\begin{array}{l}\text { My company will influence civil society } \\
\text { to promote a sustainable future }\end{array}$ & \multicolumn{2}{|c|}{$10 \%$} & \multicolumn{2}{|c|}{$90 \%$} \\
\hline
\end{tabular}

Source: Questionnaire

Our research shows a significant variation. Government may be considered 'ineffective', but $80 \%$ of the companies surveyed consider governments as their most important influence in supporting sustainability decisions made in their 
businesses. In businesses, governments thus have willing partners in improving responses towards sustainability issues. If they work in synergy they can shape market forces in a different direction towards sustainable outcomes. For example, one business may influence several governments if its supply and demand chains are international.

\section{CONCLUSIONS}

The role of governments in creating the right framework and policies is paramount for the development of a sustainable economy. Business can support and incentivise government to increase sustainable practices. One of the biggest challenges is to integrate long-term business planning into the short-term nature of political lifecycles.

\section{3) Long Term Strategic Planning}

Educate politicians and financers on the long term of sustainability risks and returns.

What is needed?

The Sustainable Economy Dialogue shows that political processes and economic pressures are against long-term thinking regarding sustainability. The UNGC survey found that although some CEOs believe that the downturn has reduced the speed at which their sustainability strategies and action plans could be integrated, the vast majority agree that the downturn has not derailed their long-term plans on these fronts (UNGC). The Economist's Intelligence Unit (2007) found that companies believe that sustainability will give them a distinct and long-term competitive advantage. 
What is actually being done?

\section{Table 3:}

\begin{tabular}{|l|c|}
\hline \multicolumn{2}{|c|}{$\begin{array}{c}\text { Which of these factors are the most important in driving your } \\
\text { company to take action on sustainability issues? }\end{array}$} \\
\hline Brand, trust and reputation & $20 \%$ \\
\hline Revenue growth & $18 \%$ \\
\hline Cost reduction & $16 \%$ \\
\hline Personal motivation & $7 \%$ \\
\hline Employee engagement and recruitment & $11 \%$ \\
\hline Impact of development gaps on business & $7 \%$ \\
\hline Governmental/regulatory environment & $16 \%$ \\
\hline Pressure from investors/shareholders & $5 \%$ \\
\hline
\end{tabular}

Source: Questionnaire

Our research shows that accurate valuation by investors and governments of sustainability in a long- term investments is needed. All companies surveyed understand the value that sustainable practices can bring to their business, shaping reputation and brand perception. Of our companies, independent owner-run firms had the advantage of being able to make long-term decisions with no short-term gains, whilst publicly listed ones did not. Unfortunately, for a majority of companies, decisions are largely driven by requirements of regular growth, short-term profits and the need to maintain their place in the financial market. Government has not challenged this.

\section{CONCLUSIONS:}

All companies surveyed agree that sustainability is about long-term planning; they believe it can shape their reputation and brand perception, and generate increased wealth for these reasons. Yet they must still operate in an economic model that demands short-term reporting and thus rewards the short-term result. So they should push further for longer-term reporting and incentivisation, which can be legislated for by governments.

\section{4) Equity}

Promote diversity and equity at corporate, community, national and international levels. 
What is needed?

Sustainable Economy Dialogue research clearly shows that there is an imbalance of opportunity, power, wealth and wellbeing in the current economy, and that changes in this regard are needed to build a fairer society.

What is actually being done?

Our companies understand the need for more equal and sustainable economic models where all stakeholders can benefit. Our research shows that a majority of the companies are supporting UN Universal Declaration of Human Rights, ILO International Labour Standards, OECD Guidelines for Multinational Enterprises, and the human rights principles of the UN Global Compact. These provide a common communication framework on which mission statements and performance can be built.

\section{CONCLUSIONS:}

For our companies, international declarations provide a foundation for signing up to equity in each of the 'five Capitals. However they cannot detach themselves completely from the current economic model. New values, new thinking and different ways to measure economic growth are necessary, and declarations on international scales have provided a useful means of beginning this. But even sustainability leaders are at the beginning of this journey.

\section{5) Responsibility}

Commit to an agenda of accountability, transparency and social and environmental responsibility.

What is needed?

The Sustainable Economy Dialogue research suggests that businesses need to participate in certain actions to foster an agenda of responsibility - for example, socially responsible activities, anti-prejudice whistle-blowing and anti-corruption corporate alliances. The UNGC survey of CEOs found that 93 percent of companies see sustainability as crucial to their future success. This requiring decoupling prosperity from growth and mitigating its negative impacts on society and the 
environment (UNGC). Businesses see this as their partial responsibility, but they also acknowledge that business with a conscience can pay financial dividends.

What is actually being done?

\section{Table 4:}

\begin{tabular}{|l|c|}
\hline \multicolumn{2}{|c|}{ What does the Code of Conduct covers? } \\
\hline Relations to employees & $16 \%$ \\
\hline Relations to customers & $26 \%$ \\
\hline Relations to suppliers & $26 \%$ \\
\hline Relations to environment & $19 \%$ \\
\hline Business transparency & $13 \%$ \\
\hline
\end{tabular}

Source: Questionnaire

The majority of our companies give almost equal importance to all three pillars of sustainability. Their codes of conduct prioritize economic and environmental issues with emphases on supply chain relations. The current economic crisis has however spotlighted businesses' greed and selfishness, indicating a wide gap between what is said and what is being done, particularly in relation to social equity. This has created widespread mistrust of businesses. Accountability and transparency within the supply chain - as well as the demand chain - create trust. For most companies the code of conduct is in place, but only the few have tested their statements through practical initiatives of this kind.

\section{CONCLUSIONS:}

People, planet and profits have to be in balance. Companies understand the urgent need for an effective approach towards the Triple Bottom Line concept. Yet when measuring growth the current economic model does not consider responsibilities to people and the environment in the equation. Businesses need to advocate sustainability responsibilities beyond their 'end product' considerations and between all those involved in the supply and demand network. This is currently a rare practice, but it is possible. 


\section{6) Incentives}

Pressure is on governments to create a level playing field for fair and international trade.

What is needed?

The Sustainable Economy Dialogue research shows that market failure and protectionist government incentives continue to foster an unjust and unsustainable economy. One of the five principal enabling conditions that executives believe need to be put in place is a regulatory environment that provides clear direction and incentives for embedding sustainability into strategy and operations (UNGC, 2010.)

What is actually being done?

Our research shows that $80 \%$ of companies believe that government should provide clearer support and direction for sustainability. They agree that more regulation and drivers to move towards an increasingly equitable and sustainable financial environment are required. The companies we approached articulated various levels of desire for partnership with governments to address these points, some pushing for higher standards, others preferring to comply with existing standards and to seek a competitive market niche from within them.

\section{CONCLUSIONS:}

Companies value the existence of clear regulations and incentives to embed sustainability within their operations. However, incentives are still heavily geared towards financial capital-focussed competition and monopolies. Initiatives from business tend to be muted unless governments allow these businesses levels of autonomy to change the marketplace. We have found this to be true in some parts of the world (notably South America) but not in others. 


\section{7) Externalities}

Incorporate full cost accounting into long-term investment decisions and begin to report on externalities.

What is needed?

Financial reforms, and new levels of dialogue between CEOs and investors and financial analysts, need further support (Sustainable Economy Dialogue). In the UNGC survey the analyst-and-investor community is critical, according to CEOs. However it is difficult for companies to make significant progress toward sustainability as an integrated way of doing business if valuations take no accounting of such efforts (UNGC, 2010).

What is actually being done?

\section{Table 5:}

\begin{tabular}{|l|c|c|c|}
\hline \multicolumn{3}{|c|}{$\begin{array}{c}\text { How important will the following changes be in order to reach a "tipping point" where } \\
\text { sustainability is embedded within the core business strategies of the majority of companies? }\end{array}$} \\
\hline $\begin{array}{l}\text { Not totally } \\
\text { important }\end{array}$ & $\begin{array}{c}\text { Less } \\
\text { important }\end{array}$ & $\begin{array}{c}\text { More } \\
\text { important }\end{array}$ & $\begin{array}{c}\text { Very } \\
\text { important } \\
+\end{array}$ \\
\hline $\begin{array}{l}\text { Majority of consumers demand products and } \\
\text { services that address sustainability challenges }\end{array}$ & $30 \%$ & $70 \%$ \\
\hline $\begin{array}{l}\text { Educational systems and business schools } \\
\text { develop mindsets and skills needed for } \\
\text { future leaders to address sustainability }\end{array}$ & $20 \%$ & $80 \%$ \\
\hline $\begin{array}{l}\text { Accurate valuation by investors of } \\
\text { sustainability in long-term investments }\end{array}$ & $10 \%$ & $90 \%$ \\
\hline $\begin{array}{l}\text { Greater value placed on a company's sustainability } \\
\text { activity by shareholders and investors }\end{array}$ & $0 \%$ & $100 \%$ \\
\hline $\begin{array}{l}\text { Boards of Directors hold management } \\
\text { accountable for sustainability objectives }\end{array}$ & $10 \%$ & $90 \%$ \\
\hline $\begin{array}{l}\text { Governments provide clearer direction } \\
\text { and support for sustainability }\end{array}$ & $20 \%$ & $80 \%$ \\
\hline $\begin{array}{l}\text { Merging of sustainability and } \\
\text { financial metrics in reporting }\end{array}$ & $25 \%$ & $75 \%$ \\
\hline $\begin{array}{l}\text { Performance on sustainability issues becomes } \\
\text { acritical differentiator in recruiting talent }\end{array}$ & $25 \%$ & $75 \%$ \\
\hline
\end{tabular}

Source: Questionnaire 
Our research shows that $75 \%$ of companies stated that it is important to merge sustainability and financial metrics in reporting. Only two suggested how this could be achieved. There is work to be done on where sustainability factors sit in relation to the investment decisions of the analyst and the shareholder, and how these bear upon future sustainability-related behaviour affecting future generations.

\section{CONCLUSIONS:}

New forms of accounting are vital in creating a new economic model that comprises all possible impacts generated by the companies' operations. These will also change the way investors and financial analysts calculate their return on investment. Most companies are still working to deliver positive results to shareholders rather than benefits to society and the environment. We must work on new ways of incorporating and tracking sustainability-related values into decision-making on the part of shareholders and general consumers. The examples given illustrate two possible ways in which this can be done.

\section{8) Purpose}

Engage in dialogue and partnership processes to create a shared vision for a sustainable economy.

What is needed?

Broadly speaking, business can influence governments and partner with civil society to deliver policies and programmes that promote sustainability outcomes (Sustainable Economy Dialogue, 2009). The UNGC survey of CEOs found that $78 \%$ of CEOs believe that companies should engage in industry collaborations and multi-stakeholder partnerships to address development goals (UNGC). 
What is actually being done?

\section{Table 6:}

\begin{tabular}{|l|c|}
\hline \multicolumn{2}{|c|}{ Please select from the list below any particular Millennium Development Goal } \\
\hline$M D G$ I Eradicate extreme hunger and poverty & $0 \%$ \\
\hline$M D G 2$ Achieve universal primary education & $0 \%$ \\
\hline$M D G$ Promote gender equality and empower women & $15 \%$ \\
\hline$M D G 4$ Reduce child mortality & $8 \%$ \\
\hline$M D G 5$ Improve maternal health & $0 \%$ \\
\hline$M D G$ 6 Combat HIV/AIDS, malaria and other diseases & $8 \%$ \\
\hline$M D G 7$ Ensure environmental sustainability & $31 \%$ \\
\hline$M D G$ \& Develop a global partnership for development & $38 \%$ \\
\hline
\end{tabular}

Source: Questionnaire

Regarding developmental goals, the leading issue for the companies surveyed is their contribution to global development partnerships. For them, most of the world's sustainability challenges need to be solved through multi-stakeholder participation. Within our research, business-to-business sustainability partnerships were hardly mentioned (UNGC however holds some excellent examples); there were some government partnerships, but it was partnerships between business and civil society that were most discussed. On one hand, our business leaders appear to be doing well in forming partnerships, as all of them revealed collaborations with other organisations as part of their Corporate Responsibility small-scale philanthropic activities. Yet on the other hand there are gaps to be filled in the scale and thus the impact of partnership activity.

\section{CONCLUSIONS:}

Sustainability will be only achieved through the shared vision of all of society's stakeholders. Companies are aware of the importance of partnerships in order to tackle the challenges of producing a more sustainable economic model. But more needs to be done to identify larger-scale and longer-term impacts resulting from shared visions. Small steps can be made fairly easily, but developments in up-scaling need to take place for such visions to have lasting and large scale impact.

\section{9) Values}

Embed values consistent with a sustainability approach into the company's culture and operations 
What is needed?

Sustainable Economy Dialogue research shows that the values underlying the current economic system may be incompatible with sustainability. However the UNGC survey of CEOs found that 81 percent of CEOs - compared to just 50 percent in 2007 - believe that sustainability issues are fully embedded into the strategy and operations of their company

What is actually being done?

The majority of our companies stated that corporate social responsibility (CSR) is embedded in their business activities and community relations as an important factor for the business. CSR reports are published by each of the companies that we researched. However there were varying degrees of success in the embedding process. In some companies sustainability values are limited to specific product/ service lines, while in others they are more deeply embedded.

\section{CONCLUSIONS:}

Sustainability cannot be only a mission statement on the wall. Companies maintain that principles of sustainability have to be embedded into their strategy and operations in order to instigate a sustainable economic model. The main challenge ahead is to find new ways of doing business that can preserve sustainability values whilst transform the economic model to a sustainable one. An important key is to consider the financial element of the 'five Capitals' - as being a means to an end, and not an end in itself.

\section{0) Measures}

Measure and report on the indicators of governance, social, ethical and environmental performance.

What is needed?

Sustainable Economy Dialogue research shows that current economic measures are poor indicators of quality of life, social wellbeing and environmental integrity. The UNGC study of CEOs shows that although businesses are making some 
progress, it is clear that executives are struggling to structure effective performance management across the business on tangible measures such as carbon, water and waste emissions management - as well as on intangible assets, such as the value of trust, reputation and effective stakeholder management.

What is actually being done?

\section{Table 7:}

\begin{tabular}{|l|c|c|c|}
\hline \multicolumn{3}{|c|}{$\begin{array}{c}\text { To what extent do you agree with each of the following statements } \\
\text { about environmental, social and corporate governance issues? }\end{array}$} \\
\hline \multicolumn{1}{|c|}{$\begin{array}{c}\text { Strongly } \\
-\end{array}$} & Disagree & Agree & $\begin{array}{c}\text { Strongly } \\
+\end{array}$ \\
\hline $\begin{array}{l}\text { These issues should be fully embedded } \\
\text { into the strategy and operations of } \\
\text { a company and subsidiaries }\end{array}$ & $0 \%$ & $100 \%$ \\
\hline Boards should discuss and act on these issues & $0 \%$ & $100 \%$ \\
\hline $\begin{array}{l}\text { Companies should embed these issues } \\
\text { through their supply chain }\end{array}$ & $0 \%$ & $100 \%$ \\
\hline $\begin{array}{l}\text { Companies should engage in industry } \\
\text { collaborations and multi-stakeholder } \\
\text { partnerships to address sustainability goals }\end{array}$ & $0 \%$ & $100 \%$ \\
\hline $\begin{array}{l}\text { Companies should incorporate these } \\
\text { as important issues into discussions } \\
\text { with financial analysts }\end{array}$ & $0 \%$ & $100 \%$ \\
\hline
\end{tabular}

Source: Questionnaire

The companies surveyed mainly agreed that the Triple Bottom Line (TBL) of economic, environmental and social business issues should be fully introduced in strategy, operations and performance management, and that their boards should act on them. Of the TBL triangle, environment tends to be the most prominent sustainability watchword. All surveyed companies affirmed that they take particular care over environmental issues in current business practice and performance improvement strategies. Environmental matters in response to legislation ensure survival, but environmental innovations present a competitive advantage. These points are applied to social issues, but figured less prominently in responses unless social issues were prominent in the company's branding. 


\section{CONCLUSIONS:}

Sustainability indicators are essential to validate business performance and create a credible and auditable sustainability index. By having an official form to measure corporate sustainable practices, this will reflect the company's contribution and commitment towards the sustainable economy; and it will influence the way it is perceived by all stakeholders. Companies need to lead the way towards new economic measures that value Capitals in addition to financial ones. Complete decoupling on a global scale may be impossible, but it can be done on a company scale.

\section{OVERALL CONCLUSIONS}

The future economy and our future depend largely on what we are going to do in the present. We have experienced the results of an unsustainable economic model, and have a very good understanding of the negative effects of this model on humankind in the long term.

All data used to produce this paper were triangulated to give a clear picture of what the role of business is in shaping a sustainable economy; what organisations perceive as necessary for such an economy; and what is needed in reality for both business and the economy.

The conclusions of our research are clear. The majority of our leading global companies understand and value sustainability as the key driver for the future economy and for their future survival. They are largely in agreement as to what actions are required to achieve sustainability; but there is still a huge gap between this consensus and the implementation of those actions.

There are strategic sustainability plans, and the desire to put them into practice is clear. This shows a great level of commitment and willingness to invest time and resources in a new sustainable economy that can benefit all stakeholders and expand the success and longevity of a business. However a great number of measures are still required for companies to walk the talk. 
It is time for companies all over the world to go beyond their current business operations. They ought to have a holistic understanding of these operations, embracing and not just compensating for their social and environmental impacts. They have to aim towards ZERO impact and if 'being sustainable' is the new world order, a 'global sustainability label' should be created to rank all products and services. Governments, industry associations, third and private sectors should come together to define the criteria in order to standardise and set criteria for the label. This label can be related to credit and risk analysis, and thus influence prices, taxes and financing rates. The same interrelation among different sectors should be used to create a single and global code of conduct embedding transparency, ethics and an honest approach in all communication with stakeholders. By doing this effectively, the educational issue would also be enhanced. Sustainability leadership would then become a differentiating factor to create trust and a vision for a sustainable future.

Climate change is a broad and complex subject that needs to be translated into effective actions; otherwise it is no more than a corporate statement. Considering the enormous diversity of business, companies need to dedicate time and resources together and within their industry to find how they can contribute to a low carbon economy aiming for the ZERO impact in their operations. Education is indicated as a key issue to create awareness among stakeholders, therefore it will be essential to ensure and promote environmental sustainability. A mandatory accounting system with tax benefits and public brand recognition can definitely contribute to a ZERO impact programme. For that, employees should be trained and incentivised to be one of the main stakeholders, capable of influencing companies' decisions about sustainability. 'Earth Funds' should be created to deal with social and environmental impacts created by the industries based on a percentage of all companies' revenues. A consortium involving civil society would administrate where and how the funds would be invested.

The sustainable economy demands a new business model as well as a new organisational model where remuneration and incentives need to stimulate the 'sustainable attitude', as distinct from the pure production reward model which has been in place since the industrial revolution. Sustainability has to become part of HR strategy where the valuation and recognition of the professional performance is related to a holistic approach centred around sustainability issues. 
Companies should organise a 'pro sustainability network' among all companies from the same sector/industry to share and create knowledge of sustainability issues. This collective database would help to co-create solutions and innovations that can maximise investments and minimise impacts/risks. In this way companies will create a standard positioning, strengthen their results and preserve their business model as a new paradigm for a sustainable economy.

The concept of 'the whole is greater than sum of its parts' is one that companies will have to embrace in order to maximise their actions. There is no competition when it comes to sustainability; it is one for all and all for one. What today is perceived as a strategic positioning to build reputation, among stakeholders it will evolve. It will become a matter of existence where we understand that we are all connected and dependable of each other.

An important and final recommendation from this paper is that we all need to understand our responsibilities as citizens of the planet and be aware that this responsibility is multiplied when wearing the corporate hat. There is no competitive advantage in creating strategic plans towards sustainability without effective implementation and constant revision and updates.

The risks of not connecting our personal and moral values with our professional responsibilities are the same as compromising the results of our business and failing with our family. The role of business in building a sustainable economy is related to our role model as individuals. Business can and will influence the future of humankind. It will depend on each one of us to create and implement the necessary changes toward a sustainable future.

"You have to be the change that you want to see in the world." M. Gandhi 


\title{
ULOGA BIZNISA U IZGRADNJ ODRŽIVE EKONOMIJE - TRENUTNI STATUS I BUDUĆI PRAVCI
}

\author{
Glomazić Rade \\ Goh Susannah \\ O’Brien Aoife \\ Conner Deb \\ Bin Julio
}

Sažetak: Postoji sve veći broj tekstova koji opisuju šta bi to trebalo poslovni svet da uradi kako bi pomogao izgradnji održive ekonomije. Samim pregledom akademske literature, istraživanjem javnog i poslownog sektora možemo uočiti ključne principe „održivog biznisa”. Ipak, kretanje ka održivoj ekonomiji je trenutno fragmentirano $i$ sa ograničenim pravcem kretanja. Ovaj rad upravo ima za cilj da istraži odnos izmedu biznisa i održive ekonomije $i$ da ukaže na to sta je potrebno da bi se oni povezali. Rad u prvom delu prikazuje istraživanje literature kako bi noćili dokaze o neodrživosti trenutnog ekonomskog modela. Takode, rad prikazuje primere naprednib kompanija koje reaguju na tražene promene. To su još uvek pojedinačni slućajevi koji ne predstavljaju pokret koji je potreban za stvaranje nove paradigme. $U$ tekstu se dalje istražuju aktuelna razumevanja uloge biznisa u tranziciji ka održivoj ekonomiji. Nakon toga, predstavljena je analiza primarnog i sekundarnog istraživanja kroz percepciju vodećih preduzeća o njihovoj ulozi u izgradnji održive ekonomije, uporedene sa realnim stanjem. Kao što ćemo videti iz istraživanja koje sledi, kompanije smatraju da je održivost od suśtinske važnosti za njibov budući poslovni uspeh (93\%) i da vlade imaju najznačajniji uticaj koji podržava donošenje odluka o održivosti u njihovom poslovanju (80\%). Takode ćemo videti da je 75\% kompanija izjavilo da je važno združiti podatke o održivosti $i$ finansijama u poslovnom izvestavanju. Ovi rezultati dovode nas, na kraju, do preporuka zapodršku ostvarivih modela $i$ smernica za kretanje ka "dobroj ekonomiji” - delotvornoj, onoj koja vodi brigu o ljudima i prirodnim i drugim resursima (CPSL. 2007). Da bi se obezbedilo da "vodeće" kompanije budu vodilja $i$ drugim kompanijama, identifikovane su $i$ konkretne kljućne preporuke za preduzeća koja jošnisu lideri budućnosti, ali koja to mogu $i$ žele postati.

Ključne reči: održivi razvoj / korporativno upravljanje / zelena ekonomija / društvena odgovornost 


\section{BIBLIOGRAPHY}

1. CPSL -Prince of Wales Business and the Environment Programme (BEP). 2004. Facing the Future: Business, Society and the Sustainable Development Challenge. Cambridge. CPSL.

2. CPSL BEP. 2007. The Sustainable Economy Dialogue, Report and Reflections. Cambridge Network

3. CPSL, (in press) The Next Economy Initiative. Cambridge, CPSL

4. Elkington, J., 1997. Cannibals with Forks, Oxford: Capstone.

5. Fitoussi, J-P., Sen, A. and Stiglitz,J., 2008. Report by the Commission on the Measurement of Economic Performance and Social Progress, The Stiglitz Commission. [Online] Available at: http://www.stiglitz-senfitoussi.fr/en/index.htm

6. Hart, S.L., 2009. Taking the Green Leap, Cornell Global Forum on Sustainable Enterprise, Centre for Sustainable Global Enterprise, Johnson School, Cornell University, New York: Cornell University.

7. Jackson, T., 2009, Prosperity Without Growth? The Transition to a Sustainable Economy, The Sustainable Development Commission, UK.

8. Pearce, D., Markandya, A. and Barbier, E., 1989. Blueprint for a Green Economy. London. Earthscan Publications.

9. Porritt, J., 2005. Capitalism, As if the World Matters. London: Earthscan.

10. Porritt, J., 2009. Living Within Our Means, Forum for the Future. [Online] Available at: http://www.forumforthefuture.org

11. Sachs, J, 2010. UN Summit New York [Online] available at: http://www. bbc.co.uk/news/world-11364717

12. Schumacher, E., 1993. Small is Beautiful: a study as if people mattered. London: Vintage.

13. Stern, N., 2007. The Stern Review on the Economics of Climate Change, HM Treasury and Cabinet Office, UK Government. [Online] Available at: http://webarchive.nationalarchives.gov.uk/+/http://www.hmtreasury.gov.uk/sternreview_index.htm

14. Stiglitz, E., Sen, A., Fitoussi, J. 2009. Report by the Commission on the Measurement of Economic Performance and Social Progress. Avaialble at http://www.stiglitz-sen-fitoussi.fr/documents/rapport_anglais.pdf 
15. UNGC, 2010. A New Era of Sustainability: United Nations Global Compact-Accenture CEO Study. [Internet] s.l.: Accenture. Available at: https://microsite.accenture.com/sustainability/documents/accenture_ ungc_study_2010.pdf

16. Wordnet, 2010. A lexical database for English. [Online] Available at: http://wordnet.princeton.edu 